\title{
Factors Influencing Farmers' Adoption of CRIN TC Cocoa Hybrid Technology in Oyo State, Nigeria
}

\author{
Jonathan Akinsola Akinwale ${ }^{1 *}$ and Oluwajoba Emmanuel Folarin ${ }^{1)}$ \\ ${ }^{1)}$ Federal University of Technology, Akure, Ondo, Nigeria \\ ${ }^{*}$ Corresponding author: jaakinwalu@ futa.edu.ng \\ Received: 17 September 2018 / Accepted: 28 October 2018
}

\begin{abstract}
Cocoa production in Nigeria has been on a downward trend in recent years. Low productivity from ageing cocoa trees and low technology uptake among the farmers are some of the contributing factors. Efforts are therefore ongoing to introduce cocoa hybrid technology to enhance cocoa farmers' productivity. This study therefore examines factors influencing adoption of CRIN TC (TC 1-8) cocoa hybrid technology among cocoa farmers in Oyo state, Nigeria. Using multistage sampling procedure, 80 respondents were sampled for the study. A wellstructured questionnaire was used to gather information from the farmers. Data was analysed using descriptive statistics and regression analysis. The results revealed that most $(83.8 \%)$ of the farmers were male with the mean age of 55 years. It also showed that $43.8 \%$ of the farmers completed primary education while majority $(51.3 \%)$ had a household size of $6-10$ persons with a mean household size of 5 persons. The study also showed that $80 \%$ of the cocoa farmers got their information regarding cocoa hybrid through research institute. It was also found that most of the farmers had high level of adoption. Meanwhile, high cost of agrochemicals was identified as a major constraint toward adoption of CRIN TC (TC 1-8) cocoa hybrid. Meanwhile, farmers age $(\beta=-0.007)$ farming experience $(\beta=-0.004)$ were identified as the factors influencing farmers' adoption of the cocoa hybrid. Governments at various levels are encouraged to subsidise the price of agrochemicals which was discovered as major constraint to adoption of CRIN TC (TC1-TC8) cocoa hybrid technology.
\end{abstract}

Keywords: Adoption, CRIN TC cocoa hybrid, cocoa technology, constraints to adoption

\section{INTRODUCTION}

Cocoa is a key cash crop in Nigeria. It accounted for 21 percent of Nigeria's agricultural exports and generated US $\$ 711$ million in 2015. Nigeria is the fourth largest global producer of cocoa, behind Ivory Coast, Indonesia and Ghana (Camargo \& Nhantumbo, 2016). However, cocoa production in Nigeria has been on a downward trend. For instance in 2014, the country's annual cocoa output declined by $34.9 \%$ to 248,000 tonnes. Meanwhile, a careful look at other cocoa producing countries in West Africa within the same period shows increase in cocoa production. For example, cocoa production in Ghana has steadily risen from 300,000 tonnes in 1995 to 900,000 tonnes in 2014 (Asante-Poku \& Angelucci, 2013) while Ivory Coast cocoa production reached $1,434,000$ tonnes in 2014 (Wessel \& Quist -Wessel, 2015). Nevertheless, with the world's rising global demand for cocoa and the growing chocolate appetite, there is the urgent need to fill the technological gap among producers (Nkamleu et al., 2010). 
Towards this end, wide adoption of improved production technology by the farmers would be necessary to boost cocoa yield and ensure sustainable production.

Innovation in agriculture has occurred over time and for ages through chance and through deliberate actions of farmers seeking for new and better ways and methods of production (Nmadu et al., 2015). But the performance of Nigerian agriculture so far indicates that the farmers have neither used nor absorbed most of the technologies being introduced to them (Akande, 1999 cit. Fawole \& Rahji, 2017). Many researchers have investigated factors related to the adoption of improved farm practices to include: farmer's age, years of education, years of experience, farm location, farm size, availability of credit, characteristics of the innovation such as relative advantage, compatibility, triability, accessibility, complexity, divisibility, sources of information and number of extension visits (Welsch, 1965; William et al., 1971; Ezeano 2010; Akinnagbe, 2017)

Nevertheless, in order to bring the country on the pedestal of self-sufficiency in cocoa production, the use of appropriate technology and innovation cannot be over-emphasized. Thus, the federal government of Nigeria through the Agricultural Research Council of Nigeria has mandated various agricultural research institutes in the country to generate technologies and promote innovation towards improving agricultural productivity. At the forefront of cocoa research is the Cocoa Research Institute of Nigeria (CRIN). In fulfillment of its mandates to agricultural development, CRIN has developed eight different cocoa hybrids known as CRIN TC Series (that is; CRIN TC1-TC8) in 2010. Each of the newly developed breeds possess distinctive features such as; early bearing (with the average yield of $2,000 \mathrm{~kg} / \mathrm{ha}$ as compared to the current $500 \mathrm{~kg} / \mathrm{ha}$ ), insect pests and disease tolerance and other quality parameters. Seedlings of these newly developed genetically improved and high yielding varieties have being made available to farmers for planting in the 14 cocoa producing states in the country.

The main objective of the study was therefore to investigate factors influencing adoption of CRIN TC1-TC8 cocoa hybrid technology among cocoa farmers in Oyo State, Nigeria. The specific objectives were to; determine the socio-economic characteristics of the respondents, identify sources of information on cocoa production, determine adoption level of CRIN TC1-TC8 cocoa hybrid and identify constraints towards farmers' adoption CRIN TC1-TC8 cocoa hybrid technology.

\section{MATERIALS AND METHODS}

The study was carried out in Oyo State, Nigeria. Oyo state is one of the 36 states of Nigeria located in the South-West geopolitical zone of Nigeria. It is bounded in the north by Kwara state, in the east by Osun state, in the south by Ogun state and in the west partly by Ogun state and the Republic of Benin. The state covers approximately 28,584 square kilometers in land area and a population of $5,591,589$. It is located between latitude $2^{\circ} 38^{\prime}$ and $4^{\circ} 35^{\prime}$ east of the Greenwich meridian. Agriculture is the major source of income for the majority of the people and the state is one of the major cocoa producing states in the country. A multistage sampling procedure was used in selecting farmers for this study. The first stage involved purposive selection of Oluyole Local Government Area (LGA). The choice of the LGA was based on the reconnaissance survey that indicated high awareness of CRIN TC1-TC8 cocoa hybrid among farmers in the LGA. In the second stage, simple random sampling 
was used to select four (4) communities in the LGA. Then using systematic random sampling, twenty (20) respondents were selected from each of the communities to give eighty (80) respondents as sample size for the study.

Farmers indicated their preferred sources of information from: Radio, Television, Extension agent, Bulletin, Blog/ Website, Friends/Fellow farmers, Short Message Service (SMS). From the list of CRIN TC1-TC8 cocoa hybrid production technology, farmers indicated their adoption using: Adopted (1) and Not Adopted (0). Also, using a three Likert type scale, farmers level of constraints were measured as: Severe Constraints (2), Mild Constraint (1), Not a Constraint (0). Descriptive statistics (such as frequencies and means) and regression analysis were used to analyze the data.

The regression equation is implicitly stated thus:

$$
\mathrm{Y}=\mathrm{f}\left(\mathrm{X}_{1}, \mathrm{X}_{2}, \mathrm{X}_{3}, \mathrm{X}_{4}\right)
$$

Where

$\mathrm{Y}=$ Adoption (dummy)

$\mathrm{X}_{1}=$ Age of farmers (years)

$\mathrm{X}_{2}=$ Farm size (ha)

$\mathrm{X}_{3}=$ Education attainment of farmers (years of formal education)

$\mathrm{X}_{4}=$ Farming experience of farmers (years)

The explicit form of the model is as below:

$$
Y=\beta_{0}+\beta_{1} X_{1}+\beta_{2} X_{2}+\beta_{3} X_{3}+\beta_{4} X_{4}+\mu
$$

\section{RESULTS AND DISCUSSION}

\section{Farmers Socio-Economic Characteristics}

Table 1 shows that $32.5 \%$ of the farmers were between the ages of 21-50 years while $67.5 \%$ were above 50 years of age. Meanwhile the mean age of the farmers was 55 years. This is almost in tandem with Nmadu et al. (2015) that found the mean age of cocoa farmers in Ondo state as 51 years. That majority of the farmers were within the old age category may lead to poor technology uptake. This is because older farmers are not receptive to innovation as they are not always willing to part with old techniques of farming (Amos, 2007 cit. Nmadu et al., 2015). The results in Table 1 further show that majority $(83.8 \%)$ of the farmers were male. This indicates male dominance in cocoa production in the study area. This corroborates with the findings of Fawole \& Rahji (2016) that found $76.4 \%$ of cocoa farmers in Ondo state to be male. Also, results in Table 1 reveal that $85 \%$ of the respondents were married and $11.3 \%$ were single. This supports Omoare et al. (2016) that found $83.4 \%$ of cocoa farmers in Ogun and Ondo states to be married. This suggests that the farmers may be willing to adopt new technology for enhanced production in order to be responsible toward family obligations that become enormous with increase in age. Meanwhile, the results in Table 1 indicate that $91.3 \%$ of the farmers had formal education (that is primary education and upward). This is expected to influence the decision making ability of the farmers as education tends to drive away ignorance. The result further shows the mean farm size of 3.4 hectares. This shows that the farmers are operating on a small scale. Thus, farmers may not be prone to adopt improved technology as a result of economies of scale from their production. Furthermore, from the results in Table 1, majority (70\%) of the respondents were members of farmers' organization while $30 \%$ did not belong to any farmers' organization. With this, the farmers are well positioned to utilize social capital to enhance their competence in farm activities. This corroborates the findings of Ofuoku et al. (2008) that farmers like to form themselves in group to carry out functions which cannot be carried out alone, for example, access to agricultural information. 


\begin{tabular}{|c|c|c|c|}
\hline Variables & $\mathrm{f}$ & $\%$ & Mean \\
\hline \multicolumn{4}{|l|}{ Age in years } \\
\hline $21-30$ & 3 & 3.7 & 55.0 \\
\hline $31-40$ & 11 & 13.8 & \\
\hline $41-50$ & 12 & 15.0 & \\
\hline $51-60$ & 22 & 27.5 & \\
\hline$>60$ & 32 & 40.0 & \\
\hline \multicolumn{4}{|l|}{ Sex } \\
\hline Male & 67 & 83.8 & \\
\hline Female & 13 & 16.2 & \\
\hline \multicolumn{4}{|l|}{ Marital status } \\
\hline Single & 9 & 11.2 & \\
\hline Married & 68 & 85.0 & \\
\hline Separated & 0 & 0.0 & \\
\hline Divorced & 0 & 0.0 & \\
\hline Widow/widower & 3 & 3.8 & \\
\hline \multicolumn{4}{|l|}{ Educational level } \\
\hline No formal education & 7 & 8.7 & \\
\hline Adult education & 0 & 0.0 & \\
\hline Primary education & 35 & 43.8 & \\
\hline Secondary education & 28 & 35.0 & \\
\hline Tertiary education & 10 & 12.5 & \\
\hline \multicolumn{4}{|l|}{ Household size (persons) } \\
\hline $1-5$ & 41 & 51.3 & 6.0 \\
\hline $6-10$ & 38 & 47.5 & \\
\hline $11-15$ & 1 & 1.3 & \\
\hline \multicolumn{4}{|l|}{ Farm size (hectares) } \\
\hline$<2$ & 28 & 35.0 & 3.4 \\
\hline $3-5$ & 44 & 55.0 & \\
\hline$>6$ & 8 & 10.0 & \\
\hline \multicolumn{4}{|c|}{ Membership of organization } \\
\hline Yes & 56 & 70.0 & \\
\hline No & 24 & 30.0 & \\
\hline
\end{tabular}

\section{Farmers' Sources of Information}

The results in Table 2 show that majority $(80.0 \%)$ of the respondents got their information regarding cocoa hybrid through research institute. This shows that CRIN is the preferred source of cocoa information for the farmers. This finding disagrees with Adeogun et al. (2010) that found radio as the most sought means of information by cocoa farmers in Nigeria. This may be as a result of proximity of the study area to the research institute coupled with the organisation's drive to popularize the hybrid among the farmers. Furthermore, $71.4 \%$ got their information from friends and fellow farmers, $66.2 \%$ got theirs through extension agents, $65 \%$ through radio, $41.3 \%$ from the ministry of agriculture, $21.4 \%$ using television, $15 \%$ through bulletin,
$10 \%$ from blog/website and while $6.2 \%$ obtained information through Short Message Service (SMS). This study shows that CRIN has been promoting cocoa production by making necessary information available to the end users. Similarly, the study reveals that friends/fellow farmers, extension agents and the use of radio are also good mechanism in disseminating cocoa information. Meanwhile, use of SMS, bulletin and blog/ website as sources of agricultural information are yet to be popular among the cocoa farmers in the study area. It is therefore expected that the arrays of information at the farmers' disposal will translate to high adoption rate of the cocoa hybrid technology. This is based on the finding of Adebiyi and Okunlola (2013) that inadequate information is one of the major impediments affecting 
Table 2. Cocoa farmers' sources of information

\begin{tabular}{|c|c|c|c|c|}
\hline \multirow{2}{*}{ Sources } & \multicolumn{2}{|c|}{ Yes } & \multicolumn{2}{|c|}{ No } \\
\hline & $\mathrm{f}$ & $\%$ & $\mathrm{f}$ & $\%$ \\
\hline Radio & 52 & 65.0 & 28 & 35.0 \\
\hline Television & 17 & 21.4 & 63 & 78.6 \\
\hline Extension agents & 53 & 66.2 & 27 & 33.8 \\
\hline Bulletin & 12 & 15.0 & 68 & 85.0 \\
\hline Blog/website & 8 & 10.0 & 72 & 90.0 \\
\hline Friends/fellow farmers & 57 & 71.4 & 23 & 28.6 \\
\hline Short Message Service (SMS) & 5 & 6.2 & 75 & 93.8 \\
\hline Research Institute (CRIN) & 64 & 80.0 & 16 & 20.0 \\
\hline Ministry of Agriculture & 33 & 41.2 & 47 & 58.8 \\
\hline
\end{tabular}

adoption of cocoa technology among farmers in Ondo State.

\section{Hybrid Technology Adoption}

The results in Table 3 show that $90.0 \%$ adopted not allowing cocoa seedlings to stay more than 5-6 months before transplanting, $88.8 \%$ adopted clearing of land with cutlass rather than burning, $87.5 \%$ adopted siting nursery close to the field, $83.8 \%$ adopted providing shade at nursery site through either palm fronds or shade net, $77.5 \%$ adopted transplanting preferably in the morning after heavy downpour, $76.3 \%$ adopted the required spacing of $3 \mathrm{~m} \times 3 \mathrm{~m}$ for transplanting seedlings, $73.7 \%$ adopted spacing of $3 \mathrm{~m}$ by $3 \mathrm{~m}$ for plantain as shade tree, $72.5 \%$ adopted establishment of shade a year before establishment of cocoa, $71.3 \%$ adopted transplanting when the rains are steady (that is, May/June), $70.0 \%$ adopted that some trees should be retained on the farm for shade provision, $63.8 \%$ adopted that nursery site should be sited near all year round water source, $60.0 \%$ adopted planting holes of $30 \mathrm{~cm}$ by $30 \mathrm{~cm}$ dug few days to transplanting, $47.5 \%$ adopted digging planting holes whereby the top soil $(15 \mathrm{~cm})$ is scooped out on one side while next $15 \mathrm{~cm}$ is put on other side, $43.7 \%$ adopted that the perimeter of nursery should be fenced with wire mesh ( $1 \mathrm{~m}$ high).

\section{Farmers' Level of Adoption}

Table 4 shows that $57.5 \%$ and $42.5 \%$ of the farmers had high and low adoption level of the cocoa hybrid series respectively. This result therefore suggests a relatively high adoption of the cocoa technology by the farmers. The high level of adoption therefore signifies that the cocoa hybrid is gaining farmers' acceptance. With this technology know out, cocoa farmers are expected to experience improved yield and livelihood. Meanwhile with further scale up for uptake in all the 14 producing states, the country is expected to recover from its dwindling cocoa production.

\section{Constraints Affecting Technology Adoption}

Table 5 shows high cost of agro-chemicals $(\overline{\mathrm{x}}=1.34)$ as the major challenge towards adoption of the cocoa hybrid. Furthermore, other constraints in the order of severity are: high routine practice $(\overline{\mathrm{x}}=1.01)$, low cocoa prices $(\overline{\mathrm{x}}=0.98)$, inadequate land $(\overline{\mathrm{x}}=0.96)$, cost of seedlings $(\overline{\mathrm{X}}=0.93)$, pests and diseases $(\overline{\mathrm{x}}=0.88)$, poor extension visit $(\overline{\mathrm{x}}=0.84)$, lack of adequate information regarding the hybrid $(\overline{\mathrm{x}}=0.73)$, soil infertility $(\overline{\mathrm{x}}=0.66)$, complexity of the technology $(\overline{\mathrm{x}}=0.60)$, low productivity $(\overline{\mathrm{x}}=0.31)$. It implies that farmers were less affected by low productivity as the technology had already improved cocoa yield. 
Table 3. Cocoa farmers' adoption of CRIN TC (TC1-TC8) cocoa hybrid technology

\begin{tabular}{|c|c|c|c|c|c|c|}
\hline \multirow{2}{*}{ Technology } & \multicolumn{2}{|c|}{ Yes } & \multicolumn{2}{|r|}{ No } & \multirow{2}{*}{ Mean } & \multirow{2}{*}{ SD } \\
\hline & $\mathrm{f}$ & $\%$ & $\mathrm{f}$ & $\%$ & & \\
\hline Nursery site should be close to the field. & 70 & 87.5 & 10 & 12.5 & 0.13 & 0.33 \\
\hline Nursery site should be sited near all year round water source. & 51 & 63.8 & 29 & 36.2 & 0.36 & 0.48 \\
\hline $\begin{array}{l}\text { The perimeter of nursery should be fenced with wire mesh } \\
\text { ( } 1 \mathrm{~m} \text { high). }\end{array}$ & 35 & 43.7 & 45 & 56.3 & 0.56 & 0.50 \\
\hline $\begin{array}{l}\text { Provision of shade at nursery site through either palm } \\
\text { fronds or shade net. }\end{array}$ & 67 & 83.8 & 13 & 16.2 & 0.16 & 0.37 \\
\hline $\begin{array}{l}\text { Cocoa seedlings should not be allowed to stay more than } \\
5-6 \text { months before transplanting. }\end{array}$ & 72 & 90.0 & 8 & 10.0 & 0.10 & 0.30 \\
\hline Land clearing with cutlass rather than burning & 71 & 88.8 & 9 & 11.2 & 0.11 & 0.32 \\
\hline Establishment of shade a year before establishment of cocoa. & 58 & 72.5 & 22 & 27.5 & 0.28 & 0.50 \\
\hline Some trees should be retained on the farm for shade provision. & 56 & 70.0 & 24 & 30.0 & 0.30 & 0.46 \\
\hline $\begin{array}{l}\text { Plantain as shade tree is to be planted at a spacing of } 3 \mathrm{~m} \\
\text { by } 3 \mathrm{~m} \text {. }\end{array}$ & 59 & 73.7 & 21 & 26.3 & 0.26 & 0.44 \\
\hline Transplanting is best when the rains are steady (May/June). & 51 & 71.3 & 23 & 28.8 & 0.29 & 0.46 \\
\hline $\begin{array}{l}\text { Transplanting is preferably in the morning after } \\
\text { heavy downpour. }\end{array}$ & 62 & 77.5 & 18 & 22.5 & 0.23 & 0.42 \\
\hline The spacing for transplanting seedlings is $3 \mathrm{~m} \mathrm{x} 3 \mathrm{~m}$ & 61 & 76.3 & 19 & 23.7 & 0.24 & 0.43 \\
\hline $\begin{array}{l}\text { Planting holes of } 30 \mathrm{~cm} \times 30 \mathrm{~cm} \text { should be dug few days } \\
\text { to transplanting. }\end{array}$ & 48 & 60.0 & 32 & 40.0 & 0.40 & 0.49 \\
\hline $\begin{array}{l}\text { Planting holes is dug whereby the top soil }(15 \mathrm{~cm}) \text { is } \\
\text { scooped out on one side while next } 15 \mathrm{~cm} \text { is put on } \\
\text { other side. }\end{array}$ & 38 & 47.5 & 42 & 52.5 & 0.53 & 0.50 \\
\hline
\end{tabular}

Table 4. Categorisation of farmers' adoption level of cocoa hybrid technology

\begin{tabular}{lcccc}
\hline Level & $\mathrm{f}$ & $\%$ & Mean & SD \\
\hline Low & 34 & 42.5 & 0.58 & 0.50 \\
High & 46 & 57.5 & & \\
Total & 80 & 100.0 & & \\
\hline
\end{tabular}

Table 5. Constraints affecting adoption of CRIN TC (TC1-TC8) cocoa hybrid technology by cocoa farmers

\begin{tabular}{lrrrrrrrr}
\hline \multirow{2}{*}{ Possible constraints } & \multicolumn{2}{c}{$\begin{array}{c}\text { Severe } \\
\text { constraints }\end{array}$} & \multicolumn{2}{c}{$\begin{array}{c}\text { Mild } \\
\text { constraints }\end{array}$} & \multicolumn{2}{c}{$\begin{array}{c}\text { Not a } \\
\text { constraint }\end{array}$} & Mean & Rank \\
\cline { 2 - 6 } & \multicolumn{1}{c}{$\mathrm{f}$} & $\%$ & $\mathrm{f}$ & $\%$ & $\mathrm{f}$ & $\%$ & \\
\hline Cost of seedlings & 21 & 26.3 & 44 & 55.0 & 15 & 18.7 & 0.93 & $5^{\text {th }}$ \\
Low productivity & 57 & 71.2 & 21 & 26.3 & 57 & 2.5 & 0.31 & $11^{\text {th }}$ \\
Pests and diseases & 20 & 25.0 & 50 & 62.5 & 10 & 12.5 & 0.88 & $6^{\text {th }}$ \\
High routine practices & 22 & 27.5 & 35 & 43.8 & 22 & 28.8 & 1.01 & $2^{\text {nd }}$ \\
Soil infertility & 32 & 40.0 & 43 & 53.8 & 5 & 6.3 & 0.66 & $9^{\text {th }}$ \\
Low cocoa prices & 23 & 28.8 & 36 & 45.0 & 21 & 26.3 & 0.98 & $3^{\text {rd }}$ \\
Inadequate land & 14 & 17.5 & 55 & 68.8 & 11 & 13.8 & 0.96 & $4^{\text {th }}$ \\
High cost of agro-chemicals & 14 & 17.5 & 25 & 31.3 & 41 & 51.3 & 1.34 & $1^{\text {st }}$ \\
Lack of adequate information regarding the cocoa hybrid & 31 & 38.8 & 40 & 50.0 & 9 & 11.3 & 0.73 & $8^{\text {th }}$ \\
Poor extension visit & 34 & 42.5 & 25 & 31.3 & 21 & 26.3 & 0.84 & $7^{\text {th }}$ \\
Complexity of the technology & 40 & 50.0 & 32 & 40.0 & 8 & 10.0 & 0.60 & $10^{\text {th }}$ \\
\hline
\end{tabular}

\section{Factors Influencing Technology Adoption}

The model for factors influencing adoption of cocoa hybrid is presented in Table 6 . The results show that age $(\beta=0.631)$ and farming experience $(\beta=-0.373)$ were the only significant variables for factors influencing adoption of cocoa hybrid. Age had a positive effect on adoption. This means that as age increases, farmers adoption of cocoa hybrid also increases. This may be as a result of mature mind of the farmers that may readily predispose them to innovation. Also, issues around family obligations with many mouths to feed that often correspond with increase in age may make the farmers to be willing to adopt innovation. This agrees with Olumba \& Rahji (2014) 
Table 6. Result of regression model of factors influencing farmers' adoption of CRIN TC (TC1-TC8) cocoa hybrid technology

\begin{tabular}{|c|c|c|c|c|c|}
\hline \multirow{2}{*}{$\begin{array}{l}\text { Variables } \\
\mathrm{n}=80\end{array}$} & \multicolumn{2}{|c|}{ Unstandardized coefficient } & \multirow{2}{*}{$\begin{array}{c}\text { Standardized } \\
\text { coefficient } \\
\text { Beta } \\
\end{array}$} & \multirow{2}{*}{$\mathrm{T}$} & \multirow{2}{*}{ Sig. } \\
\hline & B & Std. Error & & & \\
\hline Constant & -0.076 & 0.079 & & -0.961 & 0.340 \\
\hline Age & 0.007 & 0.002 & 0.631 & 4.035 & $0.001 *$ \\
\hline Experience & -0.004 & 0.002 & -0.373 & -2.381 & $0.020 *$ \\
\hline Farm size & 0.014 & 0.009 & 0.162 & 1.562 & 0.122 \\
\hline
\end{tabular}

that found age to have positive effect on farmers' adoption of improved plantain technology in Anambra State, Nigeria. Also, the negative sign with farming experience shows that as this variable increases farmers adoption of cocoa hybrid reduces and vice versa. This may be that as the farmers acquire more farming experience, they become complacent and therefore fail to show keen interest in adopting new technology. This is in contrast with the findings of Agwu et al. (2008) where farming experience had positive significance influence on adoption of improved technology. Meanwhile, the independent variables accounted for only $21.9 \%$ of factors influencing farmers' adoption of cocoa hybrid technology.

\section{CONCLUSIONS}

The preferred farmers' source of information was through CRIN. The use of SMS and blog/website were the least used sources of cocoa information by the farmers. This means that either cocoa information is not yet available both on real-time and online or the farmers are yet to be utilizing this source of information. The farmers had high adoption level of CRIN TC (TC1-TC8) cocoa hybrid. This indicates that the cocoa hybrid is already gaining farmers' acceptance. High cost of agrochemicals and high routine practices were found to be the major constraints to adoption of CRIN TC (TC1-TC8) cocoa hybrid by the farmers. Meanwhile, farmers' age and farming experience were the only factors that influenced farmers' adoption of the cocoa hybrid technology. From the aforementioned, it is therefore pertinent for researches at CRIN to supplement their outreach to cocoa farmers with SMS and online platform such as blog/website. Governments at various levels are also encouraged to subsidize the price of agrochemicals which was discovered as a major constraint to adoption of CRIN TC (TC1-TC8) cocoa hybrid technology. Also, farmers are to be supported on land preparation to expand the area of cultivation. With increased farm size, farmers would experience high economies of scale and the main source of constraints which is the cost of chemicals would be reduced. Meanwhile, concerted efforts should be focused on farmers' age and farming experience toward the adoption of CRIN TC (TC1-TC8) cocoa hybrid technology.

\section{REFERENCES}

Adebiyi, S. \& J.O. Okunlola (2013). Factors Affecting Adoption of Cocoa Farm Rehabilitation Techniques in Oyo State of Nigeria. World Journal of Agricultural Science, 9, 258-265.

Adeogun, S.O.; J.E. Olawoye \& L.A. Akinbile (2010). Information sources to cocoa farmers on cocoa rehabilitation techniques (CRTs) in selected states of Nigeria. Journal of Media Communication Studies, 2, 9-15.

Agwu, A.A.; J.N. Ekwueme \& A.C. Anyanwu (2008). Adoption of improved agricul- 
tural technology disseminated via radio farmer programme by farmers in Enugu State, Nigeria. African Journal of Biotechnology, 7, 1277-1286.

Akinnagbe, O.M. (2017). Determinant of Factors Influencing Adoption of Cocoa Resuscitation Programme in South West Nigeria. Asian Journal of Agricultural Extension, Economics and Sociology, 20, 1-9.

Asante-Poku, A. \& F. Angelucci (2013). Analysis of incentives and disincentives for cocoa in Ghana. Technical Note Series. Monitoring African Food and Agricultural Policies Project.

Camargo, M. \& I. Nhantumbo (2016). Towards Sustainable Chocolate: Greening the Cocoa Supply Chain. IIED, London.

Ezeano, C.I. (2010). Constraints to sweet potato production, marketing and utilization among small-scale farmers in SouthEastern Nigeria. Agronomical Nigeriana, 9, 280-282.

Fawole, W.O. \& R.A.Y. Rahji (2016). Determinants of productivity among farmers in Ondo State of Nigeria. Asian Journal of Agricultural Extension, Economics and Sociology, 20, 1-9.

Nmadu, J.N.; S. Halima \& B.V. Omojeso (2015), Socio-economic factors affecting adoption of innovations by cocoa farmers in Ondo State, Nigeria. European Journal of Business, Economics and Accounting, 3, 58-65.

Nkamleu; B. Guy; J. Nyemeck; J. Gockowski (2010). Technology gap and efficiency in cocoa production in West and Central Africa: Implications for cocoa sector development. Working Papers Series No. 104. African Development Bank, Tunis, Tunisia.
Ofuoku, A.U.; M. Enaikele \& A.U. Nnodim (2008). Cohesiveness of fish farmers' groups in Southern Nigeria. Journal of Agricultural and Biological Sciences, 3, 16-21.

Olumba, C.C. \& M.A.Y. Rahji (2014). An analysis of the determinants of the adoption of improved plantain technology in Anambra State, Nigeria. Journal of Agriculture and Sustainability, 5, 232-245.

Omoare, A.M.;W.O. Oyediran \& E.O. Fakoya (2016). Comparative assessment of cocoa farmers' knowledge and attitude to trainings on good cultural management practices (CMP) in Ogun and Ondo States, Nigeria. International Journal of Agricultural Extension and Rural Development Studies, 3, 36-51.

Welsch, D.E. (1965). Response of economic incentives by Abakaliki farmers in Nigeria. Journal of Farm Economics, 47, 44-52.

Wessel, M. \& P.M.F. Quist-Wessel (2015) Cocoa production in West Africa, a review and analysis of recent developments, Wageningen Journal of Life Sciences, 74, 1-7.

William, S.K.T. \& C.E. Williams (1971). Farmers contact with agricultural extension services in Western States of Nigeria. Bulletin of Rural Economics and Sociology, 6, 48-59. $* * 0 * *$ 